\title{
Building or Breaking the Polity? International Intervention, Statebuilding and Reproduction of CRisis in HAITI (2004 - 2019)
}

\author{
¿Construyendo o quebrando la comunidad política? Intervención \\ internacional, construcción del Estado y reproducción de crisis en Haití \\ (2004-2019)
}

\section{MARIANA DOS SANTOS PARRA}

University of Milan, Italy

\begin{abstract}
The article aims to investigate the role of the United Nations Stabilisation Mission in Haiti (Minustah) in the social and political landscape of the country, and how it failed to bring a sustainable contribution for peacebuilding and stabilisation, despite specific positive outcomes, especially for violence reduction and Security Sector Reform (SSR) during the period of 2006-2010. The intervention in 2004 based on violent coercion and the lack of a peace process and political settlement led the operation to aggravate, instead of treating, the social and political conflicts present in the country, contributing for the (re)production of predatory political economies, violent contestation and further social and political fragmentation. I propose that this outcome in Haiti, similar to other cases of countries with international interventions, can be better understood with a critical assessment of the peace-as-statebuilding paradigm of international interveners, and its disregard for the local legitimation of peace processes, political settlements and the building of state institutions.
\end{abstract}

Keywords: International intervention, peacebuilding, statebuilding, legitimacy, Haiti.

\section{RESUMEN}

El artículo pretende investigar el rol de la Misión de Estabilización de las Naciones Unidas en Haití (Minustah) en el escenario social y político del país, y cómo no logró hacer una contribución sostenible para la consolidación de la paz y la estabilización, a pesar de resultados positivos específicos, especialmente para la reducción de la violencia y la Reforma del Sector de Seguridad (SSR) durante el período 2006-2010. La intervención en 2004 basada en la coerción violenta y la falta de un proceso de paz y un acuerdo político llevaron a la operación a agravar, en lugar de tratar, los conflictos sociales y políticos presentes en el país, contribuyendo a la (re)producción de economías políticas predatorias, protesta violenta y a la fragmentación social y política. Propongo que este resultado en Haití, similar a otros casos de países con intervenciones internacionales, se puede comprender mejor con una evaluación crítica del paradigma de la construcción de la paz como construcción del estado por parte de los interventores internacionales, y su desprecio por la legitimación local de los procesos de paz, acuerdos políticos y la construcción de instituciones del estado.

Palabras clave: intervención internacional, construcción de la paz, construcción del estado, legitimidad, Haití. 


\section{INTRODUCTION}

The United Nations Stabilization Mission in Haiti (Minustah) operated from 2004 until 2017, and after 13 years of intervention, it left the country in the midst of an endless political crisis, with Haitians still hopeless about the possibilities to change the fate of their country, to finally reach stability and the possibility of economic prosperity and to improve the lives of the majority of its population that lives in poverty and extremely precarious conditions. Another mission was established aiming to enable an orderly transition, the United Nations Mission for Justice Support in Haiti (Minujusth), remaining in the country until October 2019, without a military component, but maintaining the UN Police.

Despite the absence of the return to a major violent conflict, Minujusth left while massive protests were happening against the government of Jovenel Moïse, with the corruption scandal of Petrocaribe, which were violently repressed, not only by the Haitian National Police, but also with the occurrence of a number of massacres in poor and marginalized areas of Port-Au-Prince by unidentified perpetrators, or in some cases paramilitaries and neighbourhood vigilantes with unclear connections (AP News 2019; The Independent 2019).

This article aims to investigate how this disastrous outcome has been produced, with the reproduction of chronic political instability and the social, economic and humanitarian crisis that affect Haiti, conditions that have developed through a long historical process, with certain local factors but undoubtedly heavy foreign interference, and that the UN mission did not contribute to tackle.

I argue that the UN intervention in 2004 aggravated, instead of treating, the conflict in Haiti at that period, and ended up contributing for the (re)production of predatory political economies, violent contestation and further social and political fragmentation. And I propose that this outcome in Haiti, similar to other cases of countries with international interventions, such as the Democratic Republic of Congo and Afghanistan, can be better understood with a critical assessment of the peace-as-statebuilding paradigm of international interveners, and its disregard for the local legitimation of peace processes, political settlements and the building of state institutions.

The article first presents a brief historical background of the case, ${ }^{1}$ so we can better understand the context and the conditions present in the country and the role played by the UN intervention. It then presents an analysis of Haiti under Minustah in three different phases, marked by certain prevalent conditions that considerably changed the social and political configuration in the country,

I am presenting here a brief historical background concerning the developments more directly connected to the crisis in 2004, eventually making references to previous events, considering that the history of Haiti is quite often analysed in the literature, not only in historical accounts but also in present sociological and political analysis. See: Trouillot 1990; Dupuy 2007; Shah 2009; Dubois 2012; Parra 2019. 
the performance of Minustah and its relation with local actors and the local population. The first phase, from 2004 until 2006, when the operation used violent coercion to contain the crisis present in the country, with an interim and unelected government; from 2006, when elections were held, René Préval was elected and positive outcomes were reached for stabilization, until 2010, with the earthquake and the contested election of Michel Martelly; and finally from 2010 until 2017, when Minustah left Haiti, being substituted by Minujusth, without a military component. The conclusion summarizes the main argument of the article, and reflects on the insights the case of Haiti can bring to the broader context of Latin American countries.

\section{BROKEN HOPES AND PROMISES - THE UNFULFILLED DEMOCRATIC TRANSITION, ARISTIDE SECOND GOVERNMENT AND THE 2004 CRISIS}

The political transition that followed the fall of Jean-Claude Duvalier in 1986 has been marked by a permanent tension between rising democratic voices fighting against a totalitarian legacy, and the Duvalierist forces that were still present in the army and in a portion of the Haitian economic and political elite (Danticat 2007; Dupuy 2007; Dubois 2012). Among difficult circumstances, the popular democratic movement had important victories, as a transitional government was established, a progressive constitution promulgated, and free and fair elections were held, with the victory of Jean Bertrand Aristide, a former priest with a social justice discourse, with the majority of votes, in February 1991 (Dupuy 2007; Dubois 2012).

His victory materialised the hope Haitians had at that moment for a radical change in the country, with which they would finally achieve freedom and democratisation. Nonetheless, eight months after his election, Aristide suffered a military coup d'état. Thousands of people were arrested, tortured and killed in the following years in the dictatorship of a military junta (Danticat 2007; Dupuy 2007; Dubois 2012).

After 30 years of the totalitarian and rentier regime of François and Jean-Claude Duvalier, which devastated the Haitian agrarian economy and society, Haitians were facing again very harsh conditions of physical and economic insecurity. An international embargo was established against the military junta, something that ended up worsening the economic hardship for the majority of the population. The formal economy shrunk, and Haiti entered in regional criminal networks, becoming a spot for international drug trafficking (Cockayne 2009: 80), with the involvement of the political and business elite. Since then, a political economy involving criminal activity, drug trafficking and political instability emerged, fuelled by high levels of unemployment, economic and social frustration (Cockayne 2009; 2014; Kolbe 2013; Muggah 2013; Marcelin 2015; Braum 2019). 
Aristide's government was restored in 1994 with the 'Operation Uphold Democracy', brought about by 20.000 US marines, with the UN Security Council approval. The US marines were substituted by blue-helmets with the United Nations Mission in Haiti (UNMIH) in the following year, remaining in the country until 1996. With his return, Aristide dissolved the Forces Armées $d^{\prime} H a i t i(\mathrm{FAdH})$. The process of demobilisation of the army, even counting on US and UN support, was still deficient, something that would turn out to be, later on, another key source of political instability (Cockayne 2009: 80; Schuberth 2017: 416).

Aristide remained in power only up to the end of his mandate, and René Préval, of Aristide's party, Lavalas, was elected in 1995, the first democratic transition of power in Haitian history (Dupuy 2007; Dubois 2012; Seitenfus 2014). The condition for Aristide's return, ultimately fulfilled by Préval, was the implementation of neoliberal measures, with privatisations and wide liberalisation of the Haitian economy, something that further worsened the situation of Haitian farmers and peasants (Shamsie and Thompson 2006; Shah 2009). In this period, Haiti became the main importer of US rice in the world, and the national rice production ended up destroyed, impoverishing thousands of farmers, something for which Bill Clinton publicly regretted (Foreign Policy 2013). ${ }^{2}$

Haitian peasants entered a new cycle of impoverishment, leaving the countryside to seek employment in the capital, Port-au-Prince, which became more and more unsustainably overpopulated, with precarious and informal settlements and without enough economic opportunities or access to proper housing, education, sanitation and health. ${ }^{3}$

Aristide's second election in 2001 marked another period of social and political instability in the country. With only $10 \%$ of turnout, his election was contested by the opposition (UN Secretary General 2004). This time, he gained strong opposition not only from the Haitian business elite for his populist rhetoric, but also from an important part of the country's working and middle class, from civil society groups and students, of diverse ideologies, including leftist and progressive sectors and many former allies (Dubois 2012: 365), and some of these groups asked for his resignation. ${ }^{4}$

There are numerous denounces of human rights abuses by Aristide's armed supporters; protests were also violently repressed in the period from 2003 to 2004 (HRW 2005). An episode at the state university in Port-au-Prince marked

Recently, civil society pressure was able to halt a similar process in the peanuts sector (Oxfam America 2016).

Haiti also suffers from an ecological collapse, being one of the most deforested countries in the world (Williams 2011; Beckett 2019: 40), something also determinant for the impoverishment of Haitian peasants, the collapse of the Haitian agrarian economy, and for the intense migration to the capital.

'Plateforme Haïtienne de Plaidoyer pour un Développement Alternatif' (PAPDA), and the feminist 'Coordination nationale de plaidoyer pour les droits des femmes' (CONAP) are examples of organisations that opposed Aristide's government, and also denounced the conditions of the external intervention in 2004 (PAPDA 2004; PAPDA 2004a). 
this phase, when gang members attacked a protest of students against the interference of Aristide's government in the university, injuring dozens of people (Braum 2014).

Aristide's government also increasingly lost its international legitimacy. One of the reasons is that he insisted that France should pay back the indemnity for the Haitian independence. ${ }^{5}$ But in the end he also lost the support from Latin American countries, several of them at that time with leftist governments, who understood that he chose a wrong path (Seitenfus 2014).

In the beginning of 2004, forces led by former FAdH members undertook a decisive violent assault against the government of Aristide, entering the country from the Dominican Republic. Part of Aristide's armed supporters turned against him in this moment, joining the offensive to end his government (Shamsie and Thompson 2006; Kolbe 2013: 4; Braum 2014: 81). On 29 February Aristide left Haiti on an American airplane. According to him, he was kidnapped, something the US government denied, alleging they were protecting Aristide's physical integrity (Dubois 2012: 364; Seitenfus 2014: 1533-1580).

On the same day, the United Nations Security Council (UNSC) approved a resolution establishing the Multinational Interim Force (MIF) under the Chapter VII of the UN Charter, authorising 'the Force to take all necessary measures to fulfil its mandate', of facilitating humanitarian assistance, providing support to the Haitian police and Coast Guard and 'to establish and maintain public safety and law and order and to promote and protect human rights'(UNSC 2004). The force was composed by troops from the United States, France, Canada and Chile (U.S. Department of State Archive 2004).

An interim government was established in March, remaining in power until elections were held in 2006. The period that followed Aristide's oust was of the most intense violent conflict, with a considerable improvement only after 2006 elections. The armed supporters of Aristide did not accept his oust from power, promoting a violent rebellion that they understood as a 'revolution' (Braum 2014). Beyond the fight between the different factions, there were many kidnappings in that period, and an alarming increase in common criminality (Kolbe and Muggah 2011; Kolbe 2013).

The approach of the UN intervention was the plain use of force. As the armed supporters of Aristide were in poor, marginalised and densely populated neighbourhoods of Port-au-Prince, MIF operations made use of indiscriminate violence, with the killing of hundreds of civilians (Kolbe 2013; Muggah 2013; Cockayne 2014). This further alienated the habitants of these neighbourhoods, as it reinforced their sense of injustice, only aggravating the social and politi-

Three of my local informants said that in their view this was a decisive factor for Aristide's fall, and this is a common opinion among Haitians (interviews with Haitians members of Haitian civil society on 11 April, 2 and 4 May 2016 in Port-au-Prince). 
cal conflict in the country. Although there were considerable changes after the establishment of Minustah, as further analysed, the operation still made use of indiscriminate violence in the Haitian 'ghettos,' mostly in the period before the 2006 elections, with the killing of civilians (Danticat 2007; Cockayne 2009; 2014; Kolbe 2013; Muggah 2013).

The context where Minustah was established was, in this way, one of strong political contestation and social conflict, where political legitimacy was contested by different groups divided by deep social, economic and class cleavages. The next section demonstrates, nonetheless, that the UN mission did not work to address this conflict, lacking a local source of legitimacy, and how this configuration contributed for the reproduction of a non-democratic political framework, connected to state and structural violence, and of the condition of chronic political instability in the country.

\section{MINUSTAH'S 'SECURITY FIRST' APPROACH, LEGITIMACY AND THE REPRODUCTION OF INSTABILITY AND CRISIS IN HAITI}

\section{4-2006: Political crisis, civil conflict, foreign intervention and Minustah security enforcement}

In 2004, Haiti was dragged in social and political conflict and violence. An important part of the civil movements that supported Aristide back in 1990's was now protesting against his increasing authoritarian tendencies and violence perpetrated by his armed supporters (Dupuy 2007, 2009; Beckett 2019). ${ }^{6}$ It is important to note that Aristide's government did not have control over these armed groups, who operated independently, and fought their 'war' from 2004 to 2006 without his leadership - it was a reaction against Aristide's oust, but not commanded by him (Braum 2014). ${ }^{7}$ Many of these groups grew in the previous decades among the political instability and successive political crises the country underwent, in the absence of the state and with the unplanned growth

\footnotetext{
See also: Movements within Haiti declared the Lavalas Government an outlaw government, PAPDA, 2 February 2004, http:/ / www.papda.org/article.php3?id_article=47, Accessed 19 July 2019.

The documentary 'Ghosts of Cité Soleil,' which presents rare footages of the areas controlled by these armed groups in 2004, also shows it, as its main character, Billy, says that Aristide abandoned them, but that they were going to fight in any case.

It is interesting to note that in Beckett ethnographic account, a man who was Aristide's supporter back in 1991 said they were expecting a call to arms from Aristide, to resist the brutal military junta, but it didn't come, as Aristide was defending a political solution. Beckett quotes him: "'We waited,' he told me, 'we waited. But nothing. We should have fought. Aristide, the international community, they said we need a political solution,' Maxo shook his head. 'You can't have a political solution to war'" (Beckett 2019: 25). Maxo was a social and environmental activist, and one among the many disillusioned with Aristide and the Lavalas movement. The fact that Aristide's political movement later recurred to the alliance with violent entrepreneurs demonstrates the strength of the pattern of use of violence for political ends in Haiti, something, as we shall see, the UN intervention did not contribute to tackle.
} 
of Port-au-Prince, with the massive migration from the countryside due to the collapse of the peasant economy (Trouillot 1990; Dubois 2012; Beckett 2014). As summarised by Cockayne:

Since that regime's demise in the late 1980s, the state's control of violence has once again fragmented: the middle and upper classes rely on highly organized private security companies, while Haiti's urban slums are controlled by neighbourhood protection rackets and gang violence (Cockayne 2009: 78).

With Aristide's populist government, these groups grew in strength and power, with the acquiescence of the government, despite their often violent and predatory behaviour. Aristide's government was not only permissive, but had connections and gave space to these groups in the government (Braum 2014; Beckett 2019). Tellingly, the Haitian historian Suzy Castor calls Aristide an "anarcho-populist" (Castor 2008).

The former FAdH soldiers (among other groups who joined them), on the other side, were mobilising and gaining strength with support and funding from foreign actors, mainly from the United States and the Dominican Republic (Kolbe 2006; Muggah 2013), ${ }^{8}$ from where they invaded Haiti to overthrow Aristide.

Despite the fact that this context clearly characterized a political crisis and conflict, contrary to most UN peace operations there was no peace process or comprehensive and minimally inclusive political settlement for the establishment of the operation, neither in the following years.

Up to the present, there is no minimal consensus in Haiti about the events of that period, around the nature and source of violence that hit the country, ${ }^{9}$ something that contributes to the continuation of political instability, social fragmentation and lack of success in democratisation.

For Aristide's armed supporters, they were fighting a war, making a revolution against those who overthrew Aristide (Braum 2014), fighting for their rights and space in Haitian society and politics. When they gave up the use of violence, in 2006, many of them say that they made the peace, and decided to work through other means to reach peace, development and to benefit their communities - the time of war was over, it was the time of development, many of them said (Braum 2014: 106-110). Although outsiders consider these groups as 'gangs,' they recognise themselves, or fall under the social category of Baz, or base, a broad category that refers to diverse associative forms, from a sim-

As the United States, the Dominican Republic has an important political influence in Haiti, from where funding to political groups come (Seitenfus 2014).

As further analysed, these divergences were clear comparing interviews with Haitians from different social and economic background, and also taking into account ethnographic accounts and other existing literature (Castor 2008; Dupuy 2008; Kolbe 2013; Muggah 2013; Braum 2014; Beckett 2019). 
ple group of friends to civic, cultural, musical and/ or political organisations (Braum 2014: 12).

Armed $B a z$ often have a predatory behaviour towards the population under their control, and they are often very unstable, following the precariousness of everyday life in the ghettos of Port-au-Prince (Braum 2014). In any case, to classify them as simple bandits, for which the solution should be simple use of violent coercion, was to completely ignore the context of these armed groups, their role in the ghettos, of offering a kind of protection to their vulnerable populations, and their political implications. As summarized by Kolbe:

Residents of popular zones have a complicated relationship with armed urban groups. Those that are more predatory inspire fear and disgust from residents while those armed urban groups which provide protective, advocacy and social services to the residents are spoken with respect and admiration, albeit with some apprehension as well (Kolbe 2013: 19).

For some of those who protested against Aristide in 2004, on the other hand, demanding political change in face of the increasing authoritarianism and violence of Aristide government, with whom I had the opportunity to talk in Haiti, the international intervention happened to actually halt their movement for democratic renovation. For them, the objective of powerful foreign actors and of the "international community" was to suppress their struggle. For this group, in this sense, the intervention did not represent a solution to the crisis, but one more problem. The fact that the armed movement who overthrew Aristide had support and funding of foreign actors, including from the United States (Cockayne 2009, 2014; Kolbe; 2013; Muggah 2013), corroborated their understanding of an international plot once again working against the democratic forces in the country.

Haitians from the educated middle class and belonging to the intellectual elite, in turn, do not recognise the violent conflict of that period as a civil war or as politically motivated, but see Aristide's supporters as common thugs (Beckett 2019). As Aristide did not address the question of the urban crisis (or urban collapse) in Port-au-Prince, further worsening it with his populist policies, much of this educated urban class started seeing Aristide's democratic model as synonymous of disorder and chaos (Beckett 2019: 29-32).

These divergent views follow deep-rooted social and class cleavages and conflicts in Haiti. The crisis of Aristide's second administration happened in the context of the long and interrupted political transition after the fall of Duvaliers' regime, as analysed in the previous section. Aristide lost the support of a progressive urban educated middle and upper class for his populist politics and connections with armed groups, for the way he was mishandling the social conflicts in the country, ending up weakening its democratic forces. The business elite and more conservative and authoritarian political class quickly took advantage, with their armed intervention to forcefully overthrow Aristide. 
Existing literature has already pointed the limitation of the 'security-first' approach of Minustah to promote stabilisation and statebuilding in Haiti (Muggah 2013), or the "futility of force" (Cockayne 2014) to tackle the problem represented by the armed baz or 'gangs' of Haitian ghettos, as the causes of their existence and the political economy around their activity went unaddressed. The physical coercion exerted by the intervention ended up reinforcing an 'anarchic' state, where entrepreneurs in the market of violence competed in turfs, with a passive acceptance by the population under their control (who often didn't have other choice) or adherence to their claims and rule, mostly young and disenfranchised males.

Kolbe summarizes this process as follows:

During this three years period of political repression, membership in armed groups across the spectrum increased. Both pro- and anti-Lavalas gangs actively sought funding and members. When ex-FAdH supported anti-Lavalas gangs and attacked pro-Lavalas gangs, it only fuelled the membership drive and accelerated violence. Crime, both that committed by political actors and crime committed by opportunistic criminals, increased (Kolbe 2013: 8).

In this sense, instead of facilitating a solution for the conflict, the intervention ended up worsening it, alienating not only those who supported Aristide and dwellers of the ghettos affected by the violence and by Minustah' military incursions in general, but also those who opposed Aristide's government and were protesting against its democratic setbacks.

Before Aristide's oust, there were attempts of negotiation to reach a political solution to the crisis led by the Caribbean Community (Caricom), with the involvement of the European Union, France, OAS and the United States (UN Secretary General 2004). Aristide accepted to negotiate, but the armed opposition refused. Nonetheless, one can question if the alternative in face of the refusal of an armed opposition with the support of foreign actors and of the Haitian business elite to negotiate was to suppress the violent rebellion and social turmoil through violent means and to establish a transitional government that, besides, had members connected to the armed opposition against Aristide (Cockayne 2009, 2014; Kolbe 2013; Muggah 2013).

Haiti did not count on legitimate state institutions for most of its history, but with the absence of a peace process and political settlement to address the conflict, the international intervention created a political void. Haitian's sovereignty was suspended (Manigat 2011), as the UN Security Council Resolution that established Minustah was under the Chapter VII of the UN Charter, authorising 'the Force to take all necessary measures to fulfil its mandate.' This political void has not been remediated with the elections and the DDR process from 2006 on, despite the improvements achieved after these processes, as we shall see, as there have not been efforts to address the deep fractures in Haitian society and 
to restore a minimal common ground for the holding of elections, government formation and political action in general - in sum, the basic rules of the democratic game.

The interim government established with the support of the international intervention did not enjoy legitimacy towards the population, not only among Aristide's supporters, but more broadly (Kolbe 2013; Muggah 2013) ${ }^{10}$; some of my interviewees pointed that transitional government members knew themselves that they were not legitimate, and that they could not, by consequence, act to tackle and intervene in the violent conflict and social turmoil from 2004 to $2006 .{ }^{11}$ The conflict and violence, in this sense, went unaddressed in this period, except for Minustah's military incursions in Haitian ghettos with the $\mathrm{PNH}$, which were, as pointed in the existing literature, ineffective, beyond the victimisation of civilians (Kolbe 2013; Muggah 2013; Cockayne 2014).

In this sense, if Aristide promoted a kind of "anarcho-populism" (Castor 2008), the UN intervention ended up contributing for the consolidation of a violent anarchical state that reigned in the country from 2004 until 2006, with different armed groups and factions, or entrepreneurs of violence, competing in the market of protection/ violence (Cockayne 2009), amid the absence of a minimally legitimate political authority.

In this period, the United States pressured Brazil to reinforce the use of coercion in the military incursions in Port-au-Prince ghettos, culminating with the suicide of the Brazilian commander of the UN troops, Lieutenant-General Urano Bacelar, in January 72006 (Seitenfus 2014). Although it is not possible to ascertain Bacelar's motivations, Seitenfus notes that he was under pressure by different actors and in divergent directions, from the leadership of Minustah, corroborating the US position, from the government of United States, and from the Brazilian government, then led by president Lula da Silva, who sustained a discourse of solidarity and cooperation among Southern developing countries and wanted a more contained and humanitarian approach in the incursions (Seitenfus 2014; Patriota 2017). This unsettling situation was the result of the lack of clarity concerning the political authority in charge in the country (or the absence of it), with multiple and unclear instances of decision.

It is reasonable to say, in this sense, that means of violent coercion were being deployed with the absence of responsibility of government, the very negation of the doctrine of Responsibility to Protect (ICISS 2001), in which we cannot

10 This understanding was expressed by most of those I interviewed in Haiti, mainly locals and foreigners who were present in the country at that time.

11 Understanding expressed in interview with a foreigner who lives in Haiti since more than three decades, representative of a development aid NGO, as well as with two Haitians representatives of civil society organisations, between April and May 2016. 
even talk about political legitimacy, for there were no proper claimants of legitimate political authority. ${ }^{12}$

If it is true that the Haitian state has historically a predatory role, governing against the Nation (Trouillot 1990), or has been often absent, or what Beckett called "the art of not governing" (Beckett 2014), the international intervention in 2004 also followed the historical pattern of foreign intervention in the country, supporting antidemocratic forces and contributing for a state of anarchic violence, instead of supporting stabilisation, conflict resolution and a path for a democratic political settlement. The use of violence to achieve political ends was, in this sense, once again reinforced in Haiti.

\section{6 - 2010: Preval's election, DDR, Community Violence Reduction and Security Sector Reform}

René Préval was elected in February of 2006, in elections considered as free and fair by international observers, without major incidents and with considerable popular participation, of around 60\% (Nordem 2006; Seitenfus 2014), something remarkable in the context of turmoil of that period. Préval was a suitable candidate in that situation: he broke with Aristide, but still had substantial support from all the Lavalas movement, which at that time was not a single party anymore; he was also well connected with the most influent countries in Haiti. Préval presented, in this sense, a conciliatory option (Seitenfus 2014), as the groups with power to influence and shape the political scenario approved his election, beyond the popular vote.

From this period on, the question of the armed groups began to be addressed, not only through the military incursions that aimed, without success, to enforce order through the use of violent coercion, but with actions to dialogue with these groups, to address their grievances and causes of violence. With a government that enjoyed some level of legitimacy in power (Cockayne 2009; 2014; Muggah 2010; Braum 2014), Minustah moved from the difficult situation of the previous period, in which it had the hands tied, to one where it had the possibility of developing more productive means to achieve its stated goal of stabilisation, having an elected government as local partner.

Préval created the National Commission for Disarmament, Dismantlement and Reintegration to pacify the territories controlled by armed groups, including inviting some among the leadership of the groups to facilitate the dialogue and the process of demobilisation (Braum 2014; Seitenfus 2014). Minustah suppor-

12 It is possible that the stronger (or only) claimants to represent a legitimate authority were the leaders of the $b a z$ who violently contested Aristide's oust. At least, according to the reports available, many of them believed in their own claims (Braum 2014; Beckett 2019; 'Ghosts of Cité Soleil'). This is not to condone their violent means and crimes, nor to say they had legitimacy among the population under their control, but only an evaluation of their self-perception and their own claims. 
ted the work of the Commission, first under the scope of the Disarmament, Demobilisation and Reintegration programme (DDR), later substituted by the projects of the Community Violence Reduction (CVR) programme (Cockayne 2014; Schuberth 2017). The UN mission supported programs of professional training, social and cultural activities and community policing.

Minustah has been responsive to local criticisms to the DDR programme, as some accused it of offering economic incentives to gang members, promoting the idea that 'crime pays' (Schuberth 2017: 421). Independently of the appropriateness of these criticisms or not, to benefit only former members of armed groups was indeed a problematic strategy in communities hit by alarming rates of poverty and extreme poverty, with general lack of educational and economic opportunities. A study showed that armed baz leaders had better levels of education then the population of these areas in general (Kolbe 2013) something that evidences the complexity of these social realities and the conflicts and tensions that permeate them.

Under the umbrella of the CVR, the UN mission started promoting and supporting projects to generate socioeconomic and cultural opportunities to people at risk of joining armed groups instead of only focusing on former members (Cockaine 2009; Kolbe 2013). Minustah worked not only with the Haitian government in these fronts but also with local and international NGOs for efforts of peacebuilding, reconciliation and social inclusion. ${ }^{13}$

Although these initiatives were key for the promotion of stabilisation, Préval's government did not get the cooperation of the urban armed groups easily - it needed to use repressive and coercive measures, especially at the beginning, undertaken by the PNH and Minustah troops, in order to make the armed baz cooperate (Cockayne 2009, 2014; Muggah 2011; Seitenfus 2014).

The UN mission, in turn, created an intelligence section to gather information and use refined tactics, with support of satellite images, to identify and arrest gang leaders without confrontations putting civilians at risk, something innovative in the context of UN peacekeeping operations (Cockayne 2014). The Joint Mission Analysis Cell (JMAC) was implemented in the second half of 2006, involving personnel from different departments of the mission.

The military component, especially with the Brazilian leadership, also started implementing practices aiming at 'winning minds and hearts' and the cooperation of populations under control of armed groups, installing a health clinic in Cité Soleil, promoting social events after military incursions "aiming to hear the feedback of the population" and to promote a better relationship with them in

13 Interview with representatives of five local and international NGOs who received support of Minustah, through the Community Violence Reduction section, to implement projects in this sense, between April and May of 2016. 
general, among other initiatives. ${ }^{14}$ It was often not hard to get the cooperation of these vulnerable populations, especially in territories worst hit by gang violence, for which these policies generated positive outcomes in the short term for violence reduction, despite the possible backlashes against those who cooperated, something of which, nevertheless, there are few reports. ${ }^{15}$

Empirical studies suggest that there were positive outcomes regarding the reduction of violence, and also regarding the Security Sector Reform (SSR) in the period between 2007 and 2010 (Kolbe and Muggah 2011; Kolbe 2013; Braum 2014). There are enquires showing an improvement of the credibility of the PNH, and that the work of Minustah, of the UNPOL as well as other efforts led by the civilian component, remarkably for the inclusion of women in the police force, to improve the attention to victims of sexual violence, and projects of community policing, contributed in this sense (Braum 2014; Hauge, Rachelle and Gilles 2015). This can be considered an important achievement, since the PNH had historically a low credibility, for rampant corruption, human rights abuses and involvement with criminal activities (Muggah 2013; Cockayne 2014).

In this way, with the improvement of the political situation, with the election of a government legitimated by the popular vote and with the support, or at least acceptance, of diverse and determinant groups in the Haitian political context, the UN mission could cooperate with and support the Haitian government for the achievement of its stated goals. From a context of the use of violent coercion without a proper political authority in the country, Minustah progressed with more productive and constructive means to address the Haitian crisis, with Haitian political authorities.

With these changes, the opinions and attitudes of locals towards Minustah changed, markedly, and paradoxically, among those who were the most affected by its military incursions in Port-au-Prince ghettos, because of the benefits and opportunities the mission facilitated to these territories after 2006. In this respect, the group of people I interviewed in Haiti entails certain bias as they were former armed baz members and communitarian leaders benefited or em-

14 Interview with Colonel Ricardo Pereira de Araujo Bezerra, commander of Minustah's Brazilian battalion, on 25 April 2016.

15 The backlash against informants is reported in Braum's ethnographic account focused in Bel Air, a traditional and old neighbourhood of Port-au-Prince which witnessed a process of impoverishment and irregular growth with the intensification of the migration from the countryside and irregular occupation of the city. According to his and other accounts (Muggah 2013; Cockayne 2014), some baz in this territory enjoy some level of acceptance by the population, depending on their leadership and behaviour, so it happened that informants got a bad reputation in these neighbourhoods, and some of them needed to leave the territory, or even Haiti (Braum 2014). In Cité Soleil, on the other hand, reports of the population's cooperation with external actors are common (Becker 2011, Interview with Colonel Ricardo Pereira de Araujo Bezerra, commander of Minustah's Brazilian battalion, on 25 April 2016.), most probably because the levels of violence in this territory are higher. Some baz leaders, leading participants of the National Commission for Disarmament, were assassinated, but some of these homicides are most probably connected to what James (2010) calls 'bureaucraft,' when individuals are accused of using external aid for their own personal advantage (Braum 2014). 
ployed by Viva Rio, a Brazilian NGO that works in favelas in Rio de Janeiro, and was invited by Minustah in 2004 to develop a similar work with poor urban communities in Haiti. Viva Rio was the biggest employer in the region of Bel Air from 2007 to 2011, among fixed, temporary or small jobs contracts (Braum 2014: 134). Other existing studies, nonetheless, also point for this increase in the cooperation and acceptance of locals towards the operation in these regions (Becker 2011; Hauge, Rachelle and Gilles 2015).

The mission did not promote opinion polls to assess its acceptance among locals, as it did in Kosovo, for instance (Lemay-Hébert 2013), and surveys on this matter are scarce. Two surveys, one performed in 2011 (Gordon and Young 2011) and another in 2012 (Schuller 2012), have some variation but mainly a very different interpretation of the results. While the first one emphasises that street protests held against Minustah, especially after the cholera contamination, did not necessarily represent the opinion of the population, tending to portray more radical sides, showing results suggesting there was support and cooperation with Minustah (something confirmed by other studies and my own field research, as already indicated), the second one emphasises the disapproval of Minustah by locals, recognising, nonetheless, that in neighbourhoods worst hit by violence, especially Cité Soleil, people tend to agree with the need for foreign troops and cooperate.

There were important differences of approach by the UN mission, as well as by the Haitian government and humanitarian and non-governmental organisations in general, in different territories with the presence of armed groups. Viva Rio's headquarters has been established in Bel Air, a region historically inhabited by an educated middle class, which underwent a process of impoverishment in the last decades, and with a history of political engagement (Braum 2014). Despite the presence of violence among different armed groups in the region, something that worsened considerably in 2012 with 'wars' among different armed $b a z$, the leaders of this region were more open to dialogue and cooperate with peacebuilding efforts, and often represented their neighbourhoods in projects of development and humanitarian assistance (Braum 2014).

In Cité Soleil, on the other hand, military operations and the policies for 'winning hearts and minds' led by the Brazilian military prevailed. ${ }^{16}$ Other actors also engaged in this region directly with the population, trying to create alternatives for them and to get their cooperation to repress and arrest members of armed groups (Becker 2011). In this sense, the means to reach local cooperation, or some level of legitimacy, varied.

The progress of the UN mission in the ghettos generated disapproval of other sectors of the Haitian society, something that evidences the complexity of the conflicts and political instability in Haiti, and also the consequences and rever-

16 Becker 2011; Interview with Colonel Ricardo Pereira de Araujo Bezerra, commander of Minustah's Brazilian battalion, on 25 April 2016. 
berations of the lack of a peace process and political settlement to address these conflicts and to complete the unfinished and troubled transition to democracy in the country.

The DDR and later CVR programmes, as well as the work with the PNH with the Security Sector Reform programme, at least promoted dialogue and some level of understanding and common ground among the security forces of the country and groups that were part of the conflict. As further analysed, nonetheless, since the political economy and clientelist networks involving urban armed groups were not addressed (Cockayne 2009; 2014), the progress achieved during this period did not last. The Haitian police, although being accused of human rights violations itself (OHCHR 2011), ${ }^{17}$ is mostly at the crossfire of the clientelist networks that are increasingly bringing back necropolitics to the country's daily life (Braum 2014; 2019).

\section{0 - 2017: Earthquake, Martelly's election and democratic reversal}

On 12 January 2010, Haiti was hit by a magnitude 7 earthquake that devastated the country. Death toll estimates vary between 80.000 and 316.000 (O'Connor 2012). The disproportionate damage and death toll occasioned by the quake should be historicised and contextualised, as pointed by Farmer (2012: 13), so one can have a reasonable understanding on this episode and its consequences for Haiti. The scale of the damage was the result of years of policies that have destroyed the Haitian agrarian economy, led to an ecological collapse, as Haiti is one of the most deforested countries in the world, and of the vastly unplanned occupation of the capital, Port-au-Prince, were the earthquake claimed more lives (Beckett 2019). In this sense, it was less a natural disaster and more a man-made catastrophe (Farmer 2012).

The earthquake happened when the country finally enjoyed some level of stability, after two decades of a tortuous and interrupted process of democratisation. The Haitian government, as well as the UN mission, took some time to properly answer to the emergency, while Haitians struggled mostly alone to get back on their feet (Seitenfus 2014), in often extreme conditions (Braum 2014). Beyond the immense material loss, the event provoked a deep traumatisation in the Haitian population, as it created one of the worst humanitarian crises ever seen (Farmer 2012; Braum 2014; Beckett 2019).

Among difficult conditions, elections were held in November of 2010, bringing a new period of instability and political contestation. Contrary to the previous

17 Recently, the most serious denounces of human rights violations in Haiti, especially the massacre perpetrated in La Saline, has not been attributed to the PNH (AlterPresse 2019); in another reported massacre, on 16 January 2019, witnesses say the perpetrators were using police uniforms, but apparently did not belong to the PNH (The Independent 2019). Both episodes happened in the context of the massive protests against the corruption scandal of PetroCaribe (BBC News 2019). 
election, there were incidents of violence and a tense environment (OAS 2011). Ricardo Seitenfus, special representative of the secretary general of the Organisation of American States (OAS) in Haiti from 2009 to 2011, denounced that there were manoeuvres for the selection of Michel Martelly by international actors, involving the chief of the UN mission, Edmond Mulet, and high level US politicians, including Hillary Clinton (Seitenfus 2014: 8071-8106). Martelly, a popular singer in the country, was in fact in third position in the first round. Jude Célestin, who was in second and would dispute the second round with Mirlande Manigat, simply disappeared from the election. He protested at the beginning, as well as Lavalas' supporters, but the politician did not go further to object the manoeuvre (Seitenfus 2014).

Martelly is an unapologetic Duvalierist (Saint-Vil 2014) and his government had a negative impact in the weak Haitian democracy. Local elections were not held - he pointed political allies to assume local offices; Parliamentary elections were also delayed for 4 years (IFES 2015). The electoral and political situation deteriorated even further in the following election, which started in October of 2015 and was concluded only in January of 2017.

Several of my local interviewees did not understand how the quality of elections in Haiti was so low while the country had a UN peacekeeping operation and heavy international presence. ${ }^{18}$ Violence and intimidation in polling stations were common, and the Haitian institutional electoral apparatus has not substantially improved, still relying on a provisional commission to manage and supervise the elections. Election's day in general is still tense in the country, as the recent past of political violence has not been completely overcome. ${ }^{19}$ There is an environment of apprehension, rumours spread easily, often causing more fear and turmoil (Braum 2014). ${ }^{20}$

Another problem reported is the disproportionate number of political party representatives, known as mandataires, in polling stations (OAS 2017). This is partly due to the high number of parties in Haiti, but also symptomatic of the fact that political actors still seek to manipulate the democratic process through means such as coercion and funding of clientelist networks.

The understanding that there was manipulation for Martelly's election was unanimous among the Haitians I interviewed. ${ }^{21}$ Martelly had, nonetheless, certain popular support, as he was a very famous and popular singer in Haiti (Braum 2014, 114). He represented a model of successful and at the same time

18 Opinion expressed by five among the Haitians I interviewed in Haiti, all of them representatives of national or international NGOs.

19 Reports on elections in Haiti inform that intimidation and violence in polling stations is still common (OAS 2011; OAS 2017). This view was also expressed by several of my interviewees, Haitians and foreigners alike.

20 Rumours are very present in the political life in Haiti, and often develop among individuals to elaborate daily life and experiences, or for the achievement of certain goals (Braum 2014; other two foreigners who spent a considerable time in Haiti also expressed this understanding). 
popular man, something that can appeal to the poor masses. His successor, Jovenel Moïse, a self-made businessman, of Martelly's political group, somehow incorporated the same appeal to the masses, despite the fast deterioration and widespread rejection of his government.

In this sense, the dubious role of Minustah in 2010's elections contributed for serious setbacks in the process of stabilisation of the country, which had progressed in the period from 2007 to 2010. It also evidently reflected in the following elections, and the use of force instead of the democratic process gained, again, protagonism in Haitian politics. Although such logic is deeply rooted in the country, the UN mission and the foreign policy of countries involved in Haiti contributed to reproduce it, instead of tackling the problem. A concrete indicator of the deterioration of the political situation in Haiti has been the continuous drop of elections turnout, ${ }^{22}$ a symptom of a more general trend of loss of hope in the country.

Furthermore, the funding of urban armed groups by political actors and businessmen showed, again, its effects after Martelly's election, something that further worsened after Minustah's departure. Street protests are, of course, a good sign of democratic participation, but in Haiti, because of this clientelist political economy, they are often one more way of making politics through coercion, or a negation of democratic politics that presuppose the need for a public space of debate and contestation, where discussion and communication among divergent views prevails over the use of force.

It is fundamental to take into account the extreme inequalities and power imbalances present in Haitian society. Nevertheless, the clientelism that connects 'ghettos' with the political class and business elite in the country, an intricate and complex web of power relations, disputes, pressure and use of economic power and violence, permeates class boundaries and turn the scenario way more complex than a more classical context of class struggle. Through these networks, subaltern groups extract material benefits, maintaining an important level of independency, but at the same time remain strongly alienated from their political agency. This malicious process further aggravates social fragmentation and distrust, which emerged and reproduced in Haiti through the years of the Duvalierist totalitarian regime and the long an interrupted transition to democracy with the brutal military junta from the 1990's.

22 The reported turnout in 2006 was of $60 \%, 22 \%$ in 2010 and $18 \%$ in 2016 (Inter-Parliament Union 2006; OAS 2011; OAS 2017). In my interviews with Haitians, the waning trust in the elections and political system was also predominant. 
If some armed baz had a certain level of acceptance by the population under their control, with considerable stability in certain neighbourhoods, after 2010 the situation started deteriorating. ${ }^{23}$ The multiple and unstable loyalties, the conflicts over scarce resources, which turned even scarcer with the departure of the UN mission in 2017, and the vicious circles entailed by the use of violence in politics and political instability, with which the political and business elite seek to control the mass of disenfranchised people - all these processes worsened up to the present as they remained unaddressed.

The process of elections in Haiti developed a complex configuration, with extreme political fragmentation, use of force, intimidation or even popular pressure during elections and after them for the extraction of benefits and to access government positions. Such clientelist relations can be merged or be confounded with demands for social justice. Braum, for instance, reports that the 'United Ghettos Movement' was founded as a grassroots movement in 2011 to start a dialogue with Martelly's administration to demand social policies and investment for development in poor urban communities. As the movement evolved, nonetheless, some of its leaders were accused of using it to get positions in Martelly's government (Braum 2014: 166-221). In this sense, although the Haitian business and political elite seek to manipulate the democratic process to defend their interests and extraction of benefits, there is also a sort of popular participation on it, what Bayart and Ellis (2000) called extraversion, something that pervades different social and economic classes.

In this way, the political scenario in Haiti has been marked by a zero-sum game (as often pointed by foreign observers and Haitians themselves) where most actors seem to be selling out the possibility of building a viable future for immediate access to benefits (in the case of the poor strata, actually often basic means of survival). The ecological crisis in the country represents a very suitable metaphor for its political crisis (the former also being deeply related to the political problems of the country), as illustrated by this passage of Beckett ethnographic work:

You can tell people not to cut down trees all you want," Cameron said, as we continued on our walk. "But they are still going to do it because they have to. No one here wants to cut down trees, except the big families that run the logging and charcoal and cement business. What are peasants going to do? Economy is gone. They can't live on dirt, so they cut trees. Charcoal is the country's leading cash crop. So, they're stuck, getting the one-off economic value of trees. But trees aren't mere commodities! Some cut trees beyond market prices. What about the medicinal value of trees things and plants? The value of a fruit tree?" For Cameron, rural Haitians were stuck in a vicious circle, caught between

23 Braum describes a series of 'wars' between armed bases in the region of Great Bel Air that started after 2010, with a considerable number of deaths. 
a declining rural economy and the demands of everyday life. Maxo had said something similar when he noted the bitter irony that Haitians cut down trees in order to survive, knowing full well that in doing so they were committing themselves, their families, and their ancestors and gods to a certain death. "It is crazy!" he had said. "They do it to live, but we all die!" (Beckett 2019: 37).

Beyond the questionable role of Minustah and other foreign actors in 2010 elections, which brought a new cycle of deterioration of the process of democratisation in Haiti, the cholera epidemics brought by UN blue helmets from Nepal was yet another factor determinant for the deterioration of the UN mission's legitimacy in the country. The contamination started on an affluent of the Artibonite River, and easily spread throughout the country, with the lack of basic infrastructure for sanitation and access to clean water, killing at least 9.000 people (The Guardian 2014; HRW 2018; PAHO and WHO 2018). The UN denied for a long period the responsibility for the contamination, even after considerable amount of evidences were available (Seitenfus 2014). When it was impossible to deny the facts and scientific evidences of the source of the epidemic, Minustah evaded responsibility blaming the lack of basic sanitation for the catastrophe (The Guardian 2016).

UN Secretary-General Ban Ki-moon apologised for the contamination only six years later, in the end of his mandate, announcing new measures and investment to fight the epidemic and help affected communities (The New York Times 2016; UN News Centre 2016;). The mismanagement of the crisis and the delay to properly answer to it occasioned many deaths that could have been prevented (The Guardian 2016a). If the UN wanted to avoid paying for all the damage and also compensation for victims, as members of the Haitian civil society demanded, the mismanagement and delay ended up creating even more costs for the international organisation, in terms of financial resources but mainly politically and for its reputation.

Another element that further damaged the local legitimacy of the operation was the cases of sexual violence and exploitation. There is a considerable consensus about the systematic nature of the problem in contexts of peacekeeping operations, including in UN documents and resolutions. ${ }^{24}$ Despite having declared a zero tolerance policy in 2003, the problem remained persistent and the process to hold perpetrators accountable flawed.

These developments not only eroded the legitimacy of Minustah and of the state institutions it was supporting to develop, but also the hope of the Haitian population in the possibility to solve the political problems in the country and to reach a minimum normality and security in everyday life. If the destruction caused by the earthquake led many to seek leaving the country to find more

24 One of the most important documents in this sense: United Nations Security Council, Resolution 2272 on Sexual Exploitation and Abuse, 11 March 2016. 
viable living conditions, the new phase of political turmoil neither help Haitians believe in the possibility of reconstruction and for a new start after the devastation.

After the earthquake, there has been an increase in violence and in the activity of armed groups, who not rarely controlled resources coming from humanitarian assistance (Kolbe 2013; Braum 2014). The international community promised billions of dollars in aid for the country. Some Haitians thought that it could be an opportunity for a new beginning, to reconstruct the country and overcome its most critical problems (Pierre-Louis 2010). This hope, unfortunately, has not been fulfilled, as the international aid after the earthquake mostly followed the common logic of immediate relief, without a consistent plan to rebuild the country. Isolated intents to improve the quality of humanitarian aid did not, evidently, met the need for a comprehensive project to develop basic infrastructure and conditions for economic development, and the vicious circle of dependency on humanitarian aid in Haiti actually received a new boost after this tragic event (Zanotti 2010; Farmer 2012; Beckett 2017).

As for the progress achieved with the SSR, it has not been followed by a considerable progress in the rule of law and judicial system, something that ended up contributing to unintended negative outcomes, with the worsening of the problem of détention préventive prolongée, that is, people imprisoned without trial, often without any judicial procedures - the condition of around $70 \%$ of Haiti's prison population (OHCHR 2017). Poor individuals often do not have access to a lawyer and spend even years without seeing a judge or other judicial authority. ${ }^{25}$ Furthermore, the crisis in the prison system peaked in the last years, with reports of inmates dying of thirst, starvation and disease (CBS News 2017). A research suggested that the population trusted more the police than the judicial system, because of its inefficiency (Hauge, Rachelle and Gilles 2015). Not surprisingly, mob justice is a common problem throughout the country (OHCHR 2017).

The electoral crisis that lasted from October 2015 to January 2017 reflected not only the democratic setback brought with Michel Martelly's election, but also the absence of a minimum ground and agreement between the different social and political forces in the country. The results were heavily contested by different political groups, and this period witnessed constant (often almost daily) street protests. Even if some of them could be spontaneous, they often reflected the precarious clientelist relations between political and business actors and groups from the 'ghettos.'

With a political stalemate that could not be solved through the electoral process and institutions, a provisional government was installed through agreements between the contesting groups, and Jocelerme Privert, that had been minister 
of the second government of Aristide ${ }^{26}$ was pointed as president, remaining in power from January 2016 until January 2017. One of my local informants affirmed that Minustah's troops bragged about their success in the pacification of troubled areas of the capital, but that in fact the 'ghettos' were quiet because they supported the transitional government in power. ${ }^{27}$

In sum, the foundational and structural problems of the UN mission limited the positive outcomes it supported bringing about for violence reduction and SSR. In the period from 2010 to 2017, Minustah's legitimacy was again heavily contested by the local population (Schuller 2012; Lemay-Hébert 2014) with the aggravating factors of the cholera contamination, the cases of human rights violations by international interveners, and their contested role in elections.

The wave of protests against the corruption scandal of PetroCaribe was certainly part of a genuine popular movement against the embezzled money that should have been invested in social and economic development. It is estimated that billions of dollars have been stolen from the programme of cooperation with the Venezuelan government. In face of the daring conditions most Haitians live, it is easy to understand the popular revolt against the scandal. This was the first time different social groups joined forces in Haiti for a common cause after decades of fragmentation and conflict.

The manipulation of violence by the business and political elite, nonetheless, complicated the scenario and hindered the political potential of this movement. As pointed by Mbembe (Mbembe 2018), we can only hope that the conscious action of those protesting against injustice and the abject structural violence pervasive in Haiti can win over the necropolitics fed by webs of power that connect local as well as international political forces (Mbembe 2003; 2012).

During the popular democratic uprising that ended Duvalierism in Haiti, student demonstrators shouted: "Long live life! Down with death!" (Dubois 2013: 359), a motto that well synthesised this movement and the democratic forces in the country at that time. Today, a necropolitical force gained, as in other cases, a different configuration from the period of Duvalierism, as tyranny transfigured from a central authority into atomized and individuated destructive force (Mbembe 2018). We can say that in Haiti, instead of ethnic and religious divisions, it materialised into a necropolitical clientelist patronage.

Besides, the danger of an authoritarian solution lurks again in the country, following the global trend of populism and politics of fear. ${ }^{28}$ Certain conserva-

26 Privert is accused of being involved in La Scierie massacre. According to the accounts of victims' relatives and human rights organisations, dozens of people were killed in the city of Saint-Marc on 4 April 2004. At that time, the city was an opposition stronghold against Aristide (Seitenfus 2014; Deibert 2016).

27 Interview with a Haitian, employee of an international NGO, on 11 April 2016.

28 This danger has been mentioned in an interview with a former employee of an international organisation in the country, on 2 May 2019. The participation of members of the dismantled Haitian army who participated in the dictatorship of the military junta in the 1990's in the reestablishment of the institution (which has a substantial popular support) evidences this danger (Reuters 2018; Miami Herald 2018). 
tism predominant in Haitian society added to the wish for minimum order and security aggravates this danger.

Many in the movement asked Jovenel Moïse's resignation, something the most influent actors in Haiti do not support (Miami Herald 2019; Minujusth 2019), pointing that "in a democracy change must come through the ballot box." As democratisation remains elusive in Haiti, with the use and manipulation of the electoral process by different political groups through coercive means, and disillusion and alienation of most of the population, the request for his resignation is understandable. The challenge seems to be the overcoming of the tradeoffs between demand for justice and compromise, revolt and security, for which a more democratic and inclusive political equilibrium is certainly needed.

\section{CONCLUDING REMARKS}

The article sought to explain how after 13 years of a United Nations peace mission in Haiti, and other 2 years of a follow-up mission, the country seems to be in a condition very similar to that it was at the beginning, with the continuation of its chronic political instability, chronic underdevelopment and a permanent state of social and humanitarian crisis. It has argued that with the use of violent coercion to solve the social and political crisis in 2004, and by not addressing the conflicts of that period, with a minimally inclusive political settlement, the intervention aggravated, instead of treated, the conflict and social crisis in that period.

Established with a mandate based on the Chapter VII of the UN Charter, characterizing Haiti as a threat to the international peace and security, the UN intervention created a political void where means of coercion were deployed by an interim, unelected and illegitimate government and by the blue helmets, whereas neither the government nor the UN intervention assumed the political authority and the 'responsibility to protect' the population under their power. This political void reinforced the undemocratic logics historically prevalent in Haitian politics, as well as the subaltern position of the country in the international scenario.

Despite the improvements and positive outcomes achieved mainly in the period from 2006 to 2010, with considerable stabilization and improvement of the security sector, the lack of a comprehensive political settlement, as well as the subsequent negative impacts of the operation, notably with the election of Michel Martelly in 2010, which brought important setbacks to the process of democratization, led the international intervention in Haiti to contribute for the reproduction of the predatory and neopatrimonial political economy prevalent in the country.

The tricky question for Haiti and other places affected by chronic political instability, violence and underdevelopment is that the functioning and reproduc- 
tion of political and economic webs of power are regionally and internationally intertwined, are strongly influenced by forces these societies cannot control, and that shape the behaviour, bring resources and legitimation to political actors, decisively weakening the power of these societies to pressure and influence politics from the bottom-up.

At the same time, a path to overcome violence, instability and economic stagnation can only be pursued by local agents and societies themselves, with their protagonism. Following externally imposed, ready-made recipes and procedures, undergoing externally-driven social and political engineering, have proved not only to be ineffective, but also to contribute for the reinforcement of local power imbalances, populations' disempowerment and alienation, and corrupt and predatory political orders (Autesserre 2010; Veit 2010; Jones 2013; Barma 2017; Parra 2019).

Despite the fact that Haiti has been the only country in the Americas that received a UN peacekeeping operation (with a civil and military component), other countries in the region with similar conditions also face this conundrum, the conundrum of many postcolonial societies affected by heavy foreign interference, regional and global geopolitics: only they can change their conditions, build more inclusive and accountable political institutions and defeat extractive and exclusionary economic and political actors that monopolize access to wealth, resources and power. But their ability to do so, the conditions for the political agency of an important part of these populations, is often very limited, shortened by power structures that are often very far and not accountable to them.

As global inequalities grow, global governance mechanisms are still ill equipped to deal with the consequences of decades, or centuries of destructive policies that dragged postcolonial societies into poverty, social fragmentation and state failure. If international governmental and non-governmental organizations aim to support these societies, they should work in order to avoid supporting the reproduction of local predatory political economies, as local entrepreneurs use the power, resources and legitimacy conferred by these international actors to maintain their extractive practices. They should strive to support the progressive increment of the social and political agency of populations affected, of their economic independence, their ability to make choices and act politically.

The danger of reinforcing local power imbalances and extractive practices is present not only in UN interventions, but in humanitarian and development aid in general. On the other hand, Latin America is also scenario of numerous initiatives that aim to empower those affected by conflict, violence, poverty and exclusion (Hancock 2018; Masullo 2018), including in Haiti itself (Zanotti 2010). Hopefully these approaches will become more the rule than the exception in the trying times we are presently living, where inequalities at the local and global levels aggravate the many challenges we are facing. 


\section{REFERENCES}

AlterPresse. 2019, 5 April. “Haiti facing worst crisis since 1986?" Retrieved 29 September 2019 from https:/ /www.alterpresse.org/spip.php?article24204\#.XXakYCgzbIU.

AP News. 2019, 7 June, "Leader or killer? A day with 'Barbecue' in Haiti's capital." Retrieved 29 September 2019 from https://www.apnews.com/ebc2cee089f149309bd73afa07816a63?utm_source $=$ Twitter\&utm_campaign $=$ SocialFlow\&utm_medium $=$ AP

Autesserre, Séverine. 2010. The trouble with the Congo: Local violence and the failure of international peacebuilding. Cambridge: Cambridge University Press.

Barma, Naazneen H. 2017. The Peacebuilding Puzzle: Political Order in Post-Conflict States. Cambridge: Cambridge University Press.

Bayart, Jean-François, and Stephen Ellis. 2000. "Africa in the world: a history of extraversion." African Affairs 99 (395): 217-267.

BBC. 2019, 18 June. "Haiti protests: Why are so many people on the streets?" Retrieved 19 July 2019 from https: / / www.bbc.com/news/av / world-latin-america-48665945/haiti-protests-why-are-so-many-people-on-the-streets?fbclid=IwAR1wgpyOH26pFWayIoEBm56BwR_EipyW21Kf0nU4lWAjr46GbhXPFj5aCS4.

Beckett, Greg. 2014. "The Art of Not Governing Port-au-Prince." Social and Economic Studies (63)2: 31-57.

Beckett, Greg. 2017. "A Dog's Life: Suffering Humanitarianism in Port-au-Prince, Haiti." American Anthropologist 119(1): 35-45.

Beckett, Greg. 2019. There Is No More Haiti: Between Life and Death in Port-au-Prince. California: University of California Press

Becker, David C. 2011. "Gangs, Netwar, and" Community Counterinsurgency" in Haiti." Prism 2(3): 137-154.

Braum, Pedro. 2014. Rat pa kaka: Política, Desenvolvimento e Violência no Coração de Porto Príncipe. Tese de Doutorado apresentada ao Programa de Pós-Graduação em Antropologia Social, Museu Nacional, da Universidade Federal do Rio de Janeiro - UFRJ.

Braum, Pedro. 2019. "Frustração". In Conversas Etnográficas Haitianas, edited by Federico Neiburg, Rio de Janeiro: Papéis Selvagens, 131-158.

Castor, Suzy. 2008. "La transición haitiana: entre los peligros y la esperanza". Observatorio Social de América Latina 8(23): 25-38.

CBS News. 2017, 21 February. "Mass funeral held for inmates who died in "cruel, inhuman" Haitian prison," Retrieved 21 March 2019 from http://www.cbsnews.com/news/ families-mourn-after-20-haitians-die-in-dismal-prison/.

Cockayne, James. 2009. "Winning Haiti's Protection Competition: Organized Crime and Peace Operations Past, Present and Future." International Peacekeeping 16(1): 77-99.

Cockayne, James. 2014. "The Futility of Force? Strategic Lessons for Dealing with Unconventional Armed Groups from the UN's War on Haiti's Gangs." Journal of Strategic Studies 37(5): 736-769.

Danticat, Edwidge. 2007. Brother, I'm Dying. New York: A. Knopf Book.

Deibert, Michael. 2016, 17 February. "The fêted and the dead in Haiti," Retrieved 25 March from http://michaeldeibert.blogspot.com/2016/02/the-feted-and-dead-in-haiti. html).

Dubois, Laurent. 2012. Haiti: The Aftershocks of History. New York: Macmillan.

Dupuy, Alex. 2007. The Prophet and Power: Jean-Bertrand Aristide, the International Community, and Haiti. Texas: Rowman \& Littlefield Publishers.

Dubois, Laurent. 2012. Haiti: The Aftershocks of History. New York: Macmillan.

Farmer, Paul. 2012. Haiti After the Earthquake. Public Affairs: Perseus.

Gordon, Grant M., and Lauren E. Young. 2017. "Cooperation, information, and keeping the peace: Civilian engagement with peacekeepers in Haiti." Journal of Peace Research 54(1): 64-79.

Hancock, Landon E. 2018. "Legitimate Agents of Peacebuilding: Deliberative Governance in Zones of Peace." In Local Peacebuilding and Legitimacy: Interactions Between National and 
Local Levels, edited by Landon E Hancock and Christopher Mitchell. Oxon: Routledge, 20-42.

Hauge, Wenche, Rachelle Doucet, and Alain Gilles. 2015. "Building Peace from Below-the Potential of Local Models of Conflict Prevention in Haiti." Conflict, Security \& Development 15(3): 259-282.

Human Rights Watch (HRW). 2005. “Events of 2004 - Haiti. “ Retrieved 12 June 2018 from https:/ / www.hrw.org/world-report/2005/country-chapters/haiti

Human Rights Watch (HRW). 2019. “Haiti - Events of 2018." Retrieved 7 July 2019 from https://www.hrw.org/world-report/2019/country-chapters/haiti.

International Commission on Intervention, State Sovereignty, \& International Development Research Centre (Canada). 2001. "The Responsibility to Protect: Report of the International Commission on Intervention and State Sovereignty." IDRC.

International Foundation for Electoral Systems (IFES). 2015, 6 August. "Elections in Haiti: 2015 Legislative Elections." Retrieved 14 May 2018 from http://www.ifes.org/faqs/ elections-haiti-2015-legislative-elections.

Inter-Parliament Union Haiti. 2006. "Elections held in 2006." Retrieved 16 May 2018 from http:/ /archive.ipu.org/parline-e/reports/arc/2138_06.html.

James, Erica Caple. 2010. Democratic Insecurities: Violence, Trauma, and Intervention in Haiti. California: University of California Press.

Jones, Lee. 2013. "State theory and statebuilding: Towards a Gramscian analysis." In New Agendas in Statebuilding: Hybridity, Contingency and History, edited by Robert Egnell and Peter Haldén. Routledge, 70-91

Kolbe, Athena and Royce A Hutson. 2006. "Human Rights Abuse and Other Criminal Violations in Port-au-Prince, Haiti: a Random Survey of Households." The Lancet, 864-873.

Kolbe, Athena and Robert Muggah. 2011. "Securing the State: Haiti Before and After the Earthquake." Small Arms Survey. Retrieved 1 August 2020 from http://www.smallarmssurvey.org/fileadmin/docs/A-Yearbook/2011/en/Small-Arms-Survey-2011Chapter-08-summary-EN.pdf.

Kolbe, Athena. 2013. Revisiting Haiti's Gangs and Organized Violence. Instituto Igarapé. Retrieved 7 September 2018 from https: / /igarape.org.br/revisiting-haitis-gangs-and-organized-violence/.

Lemay-Hébert, Nicolas. 2013. "Everyday Legitimacy and International Administration: Global Governance and Local Legitimacy in Kosovo." Journal of Intervention and Statebuilding 7(1): 87-104.

Lemay-Hébert, Nicolas. 2014. "Resistance in the Time of Cholera: The Limits of Stabilization Through Securitization in Haiti." International Peacekeeping 21(2): 198-213.

Leth, Asger and Milos Loncarevic. 2020. "Ghosts of Cité Soleil." Video documentary. Retrieved 18 July 2020 from https:/ /www.imdb.com/title/tt0479046/?ref_=fn_al_tt_1

Manigat, Mirlande. 2011. "The Legacy of the 1987 Constitution: Reform or renewal?" In Fixing Haiti: MINUSTAH and Beyond, edited by Jorge Heine and Andrew S. Thompson, United Nations University Press, 66-77.

Marcelin, Louis Herns. 2015. "Violence, Human Insecurity, and the Challenge of Rebuilding Haiti: A Study of a Shantytown in Port-au-Prince." Current Anthropology (56)2: 241242.

Masullo, Juan. 2018. “Noncooperation as a Source of Legitimacy - Innovative Youth Reactions in the Face of Local Violence." In Local Peacebuilding and Legitimacy - Interactions Between National and Local Levels, edited by Landon E. Hancock and Christopher Mitchell. Routledge, 63-83.

Mbembe, Achille. 2003. "Necropolitics." Public Culture (15)1: 11-40.

Mbembe, Achille. 2012. "Metamorphic Thought: the Works of Frantz Fanon." African Studies (71)1: 19-28.

Mbembe, Achille. 2018. "Lumpen-Radicalism and Other Diseases of Tyranny." In Sustaining Peace. Brot für die Welt - Evangelischer Entwicklungsdienst (BfdW). 
Miami Herald. 2018, 26 March. "Haiti has a new army with much of the old leadership. Some in the U.S. aren't happy." Retrieved 17 July 2018 from https://www.miamiherald. com/news/nation-world/world/americas/haiti/article206915699.html

Miami Herald. 2019, 20 June. "OAS tells Haiti opposition to back off - and tells president to start governing." Retrieved 19 July 2019 from https://www.miamiherald.com/ news/nation-world/world/americas/haiti/article231731618.html.

Muggah, Robert. 2010. "The Effects of Stabilization on Humanitarian Action in Haiti." Disasters 34(3): 444-463.

Muggah, Robert. 2013. "The Political Economy of Statebuilding in Haiti - Informal Resistance to Security-First Statebuilding." In Political Economy of Statebuilding - Power After Peace, edited by Mats Berdal and Dominik Zaum. New York: Routledge, 93-305.

Norwegian Centre for Human Rights (Nordem). 2006, April. “Report - Haiti: Presidential and Legislative Elections, February - April 2006". Retrieved 1 August from https:/ /www. jus.uio.no/smr/english/about/programmes/nordem/publications/2006/1506.pdf

Office of the High Commissioner for Human Rights (OHCHR). 2011, December. "Haiti, Human Rights Section Minustah, Report on Alleged Killings by Haitian National Police and the Response of State Authorities" Retrieved 1 August from https:/ / www.ohchr. org/Documents/Countries/HT/Report_on_killings_en.pdf.

Office of the High Commissioner for Human Rights (OHCHR). 2017, 13 March. "L'Expert indépendant de l'ONU présente ses conclusions au terme de sa mission en Haïti." Retrieved 10 February 2018 from https://www.ohchr.org/FR/NewsEvents/Pages/ DisplayNews.aspx?NewsID=21352\&LangID=F.

Organisation of American States (OAS). 2011, 13 January. "Final Report - Expert Verification Mission of the Vote Tabulation of the November 28, 2010 Presidential Election in the Republic of Haiti." Retrieved 14 May 2018 from http://scm.oas.org/pdfs/2011/ CP25512E.pdf

Organisation of American States (OAS). 2017, 29 January. "Report to the permanent council, Electoral Observation Mission - Haiti, General Elections." Retrieved 14 May 2018 from http://www.oas.org/documents/eng/press/Informe-Final-Haiti-CP-2017ENG.pdf.

Organisation of American States (OAS). 2017, 12 September. "Report to the Permanent Council, Electoral Observation Mission - Haiti, General Elections" Retrieved 14 May 201 from http://www.oas.org/documents/eng/press/Informe-Final-Haiti-CP-2017ENG.pdf.

Oxfam America. 2016, 6 April. “Dumping peanuts on Haiti.” Retrieved 7 September 2018 from https://politicsofpoverty.oxfamamerica.org/2016/04/dumping-peanuts-on-haiti/

O'Connor, Maura R. 2013, 11 January. "Subsidizing Starvation." Foreign Policy. Retrieved 4 September 2018 from https://foreignpolicy.com/2013/01/11/subsidizing-starvation/.

O'Connor, Maura R. 2012, 12 January. “Two Years Later, Haitian Earthquake Death Toll in Dispute." Columbia Journalism Review. Retrieved 19 March 2018 from https://archives.cjrorg/behind_the_news/one_year_later_haitian_earthqu.php.

Pan-American Health Organisation and World Health Organisation. 2018, 11 October. "Epidemiological Update - Cholera." Retrieved 5 September 2018 from https:/ / reliefweb. $\mathrm{int} /$ sites/reliefweb.int/files/resources/2018-oct-11-phe-epi-update-cholera.pdf.

Parra, Mariana dos Santos. 2019. "Minustah's Legitimacy and the 'Security-First' Approach: Reassessing Statebuilding and its Violent Features in the Case of Haiti." Journal of Intervention and Statebuilding 13(4): 480-502.

Patriota, Antonio de Aguiar. 2017. "Is the World Ready for Cooperative Multipolarity?." Rising Powers Quarterly 2(2): 15-29.

Plateforme Haïtienne de Plaidoyer pour un Développement Alternatif' (PAPDA). 2004, 2 February. "Forces vives d'Haiti décrétent le Gouvernement Lavalas hors la loi." Retrieved 7 June 2018 from http:/ / www.papda.org/article.php3?id_article=48 
Plateforme Haïtienne de Plaidoyer pour un Développement Alternatif' (PAPDAa). 2004, 12 September. "Les causes de la chute d'Aristide en 2004." Retrieved 7 June 2018 from http:/ / www.papda.org/article.php3?id_article=44

Pierre-Louis, Michèle. 2010, 27 March. "My Pride and Hope for Haiti." Retrieved 19 July 2019 from https:/ /www.huffpost.com/entry/my-pride-and-hope-for-hai_b_435398?guccounter=1\&guce_referrer=aHR0cHM6Ly9lbi53aWtpcGVkaWEub3JnLw\&guce_referrer_sig=AQAAAN12hpZkkzMxKDP2HvSRnYA0FXOjvgRg_xHnjsBJ3RfZKbtuy2PoiorB_ZmvPaZBIoObzjnlViHqrssIIgZZ-EUtKLxp6FGDThtUyNM_3AODjo0Sz4xlm6kqFQcSpg33pDyCeYwhDlREqUeCCW4A8LcdEU0Skl8Y02d6tpMygf.

Reuters. 2018, 28 March. "Haiti installs new high command for planned 5,000-strong army." Retrieved 7 July 2018 from https:/ /www.reuters.com/article/us-haiti-military/haiti-installs-new-high-command-for-planned-5000-strong-army-idUSKBN1H40CV.

Saint-Vil, Jean. 2014, 16 August. "The Clintons, Duvalier, Martelly and Haiti." Centre for Research on Globalization. Retrieved 14 May 2018 from https:/ /www.globalresearch.ca/ the-clintons-duvalier-martelly-haiti/5396127

Seitenfus, Ricardo. 2014. Haiti: Dilemas e Fracassos Internacionais. Ijuí: Editora Unijui.

Schuller, Mark. 2012, 14 Febraury. "Is it Time for MINUSTAH to Leave? Popular Perceptions of the UN Stabilization Mission in Port-au-Prince, Haiti." York College. Retrieved 17 July 2019 from http://ijdh.org/wordpress/wp-content/uploads/2012/02/MINUSTAH-Report.pdf.

Schuberth, Moritz. 2017. “Disarmament, Demobilization and Reintegration in Unconventional Settings: the Case of MINUSTAH's Community Violence Reduction." International Peacekeeping 24(3): 410-433.

Shah, Kamil. 2009. "The Failure of State Building and the Promise of State Failure: Reinterpreting the Security-Development Nexus in Haiti." Third World Quarterly 30(1): 17-34.

Shamsie, Yasmine, and Andrew S. Thompson (ed). 2006. Haiti: Hope for a Fragile State. Waterloo: Wilfrid Laurier University Press.

Smith, Charles Anthony and Heather M. Smith. 2011. "Human Trafficking: The Unintended Effects of United Nations Intervention". International Political Science Review 32(2): 125-145.

The Guardian. 2014, 11 March. "Haitians launch new lawsuit against UN over thousands of cholera deaths." Retrieved 5 September 2018 from https://www.theguardian.com/ world /2014/mar/11/haiti-cholera-un-deaths-lawsuit.

The Guardian. 2014a, 14 April. “UN could have prevented Haiti cholera epidemic with $\$ 2,000$ health kit - study." Retrieved 7 September 2018 from https: / www.theguardian.com / world/2016/apr/14/haiti-cholera-epidemic-un-prevention?CMP=share_btn_fb

The Guardian. 2016, 5 April. "Leaked UN report faults sanitation at Haiti bases at time of cholera outbreak." Retrieved 5 September 2018 from https://www.theguardian.com/ world/2016/apr/05/leaked-un-report-sanitation-haiti-bases-cholera-outbreak?CM$\mathrm{P}=$ share_btn_fb.

The Independent. 2019, 16 January. "Men in police uniforms 'massacre' unarmed civilians in Haiti." Retrieved 28 September 2019 from https://www.independent.co.uk/news/ world/americas / haiti-massacre-port-au-prince-police-uniforms-gangs-united-nations-a8729876.html

The New York Times. 2016, 1 December. “U.N. Apologizes for Role in Haiti's 2010 Cholera Outbreak." Retrieved 7 September 2018 from https:/ /www.nytimes.com/2016/12/01/ world/americas/united-nations-apology-haiti-cholera.html.

Thomaz, Omar Ribeiro. 2010. "O Terremoto no Haiti, o Mundo dos Brancos e o Lougawou." Novos Estudos (86):23-39.

Trouillot, Michel-Rolph. 1990. Haiti: State Against Nation - The Origins and Legacy of Duvalierism. New York: Monthly Review Press.

United Nations News Centre. 2016, 1 September. "UN's Ban apologizes to people of Haiti, outlines new plan to fight cholera epidemic and help communities." Retrieved 7 
September 2016 from http://www.un.org/apps/news/story.asp?NewsID=55694\#. WSgoQGjyjIV.

United Nations Mission for Justice Support in Haiti (Minujusth). 2019, 10 Febraury. Press Release of the Core Group. Retrieved 29 July 2019 from https:/ / minujusth.unmissions. org/en/press-release-core-group-\%E2\%80\%93-10-february-2019.

U.S. Department of State Archive. 2004, 15 March. "Political, Security, and Civil Developments in Haiti." Retrieved 19 July 2019 from https://2001-2009.state.gov/p/wha/ rls/30486.htm.

Veit, Alex. 2010. Intervention as indirect rule: Civil war and statebuilding in the Democratic Republic of Congo. New York: Campus Verlag.

Zanotti, Laura. 2010. "Cacophonies of Aid, Failed State Building and NGOs in Haiti: Setting the Stage for Disaster, Envisioning the Future." Third World Quarterly 31(5): 755-771.

Williams, Vereda Johnson. 2011. "A case study of desertification in Haiti." Journal of Sustainable Development 4(3): 20-31

Received: April 29, 2020

Accepted: July 18, 2020

Mariana dos Santos Parra holds a PhD in Political Studies by the University of Milan, Italy. Email: mariana.dossantos@unimi.it 